\title{
Clinical aspects, food management, and clinical evolution of a cat with hypertrophic muscular dystrophy
}

\author{
Mathias Reginatto Wrzesinski ${ }^{1}$ (D) Marcelo Luís Schwab ${ }^{1}$ (D) Dênis Antonio Ferrarin ${ }^{1}$ (D) \\ Angel Ripplinger ${ }^{1}$ (D) Júlia da Silva Rauber $^{1}$ (D) Marcia Cristina da Silva ${ }^{2}$ (D) \\ Maria Angélica Miglino ${ }^{3}$ (D) Gustavo de Sá Schiavo Matias $^{3}$ (D) Alexandre Mazzanti ${ }^{*}$
}

\footnotetext{
${ }^{1}$ Programa de Pós-graduação em Medicina Veterinária, Serviço de Neurologia e Neurocirurgia Veterinária, Hospital Veterinário Universitário (HVU), Centro de Ciências Rurais (CCR), Universidade Federal de Santa Maria (UFSM), Santa Maria, RS, Brasil. ${ }^{2}$ Qualem Laboratório Veterinário, Santa Maria, RS, Brasil.

${ }^{3}$ Faculdade de Medicina Veterinária e Zootecnia, Universidade de São Paulo, São Paulo, SP, Brasil.

${ }^{4}$ Departamento de Clínica de Pequenos Animais, Serviço de Neurologia e Neurocirurgia Veterinária, Hospital Veterinário Universitário (HVU), Centro de Ciências Rurais (CCR), Universidade Federal de Santa Maria (UFSM), 97105-900, Santa Maria, RS, Brasil. E-mail: alexamazza@yahoo.com.br. "Corresponding author.
}

ABSTRACT: Hypertrophic feline muscular dystrophy (HFMD), rarely reported in the literature, is a disease caused by a hereditary recessive dystrophin deficiency linked to the X chromosome, mainly affecting young male cats. Here, we presented the clinical aspects, food management, and clinical evolution of a seven-year-old mixed-breed cat diagnosed with HFMD, having a primary history of progressive tongue protrusion. Key words: feline muscular dystrophy, dystrophin, protrusion, biopsy, cat.

Aspectos clínicos, manejo alimentar e evolução clínica de um gato com distrofia muscular hipertrófica

RESUMO: A distrofia muscular hipertrófica felina é uma doença causada por uma deficiência da distrofina com caráter hereditário recessivo ligado ao cromossomo $X$, com poucos registros de ocorrência na literatura, que acomete principalmente gatos machos jovens. Neste trabalho, são relatados os aspectos clínicos, manejo alimentar e evolução clínica de um gato, sem raça definida, de sete anos com histórico principal de protrusão progressiva da língua e diagnosticado com distrofia muscular hipertrófica felina.

Palavras-chave: distrofia muscular felina, distrofina, protrusão, biópsia, gato.

Muscular dystrophies caused by dystrophin deficiency have been reported in humans, mice (TORRES \& DUCHEN, 2007), and dogs (KORNEGAY et al., 1988; YUASA et al., 2008). In cats, the common form is hypertrophic feline muscular dystrophy (HFMD) (GASCHEN et al., 1999), already reported in North America, Holland, Switzerland, France, United Kingdom, and Belgium (CARPENTER et al., 1989; GASCHEN et al., 1992, 1999; CHETBOUL et al., 2006; VAN SOENS et al., 2009; BLUNDEN \& GOWER, 2011). In Brazil; although, cats with this disease may be prevalent, no reports are yet available in the literature.

The clinical complications associated with HFMD can lead to death or severe implications for the animal's well-being, culminating in euthanasia for most young cats with the disease. (CARPENTER et al., 1989; GASCHEN et al., 1999; VAN SOENS et al., 2009; BLUNDEN \& GOWER, 2011). In some situations; however, the cats' quality of life can be improved with proper management (GASCHEN et al., 1999).

The present report presented a case of HFMD and demonstrate the clinical features, along with laboratory, imaging, histopathological, and immunohistochemical findings. In addition, our study has described the food management and clinical evolution, following 22 months of diagnosis.

A feline, male, seven-year-old mixed breed, with a history of tongue protrusion since the age of three (Figure 1A), was referred to a veterinary University hospital. The evolution was progressive, with the 


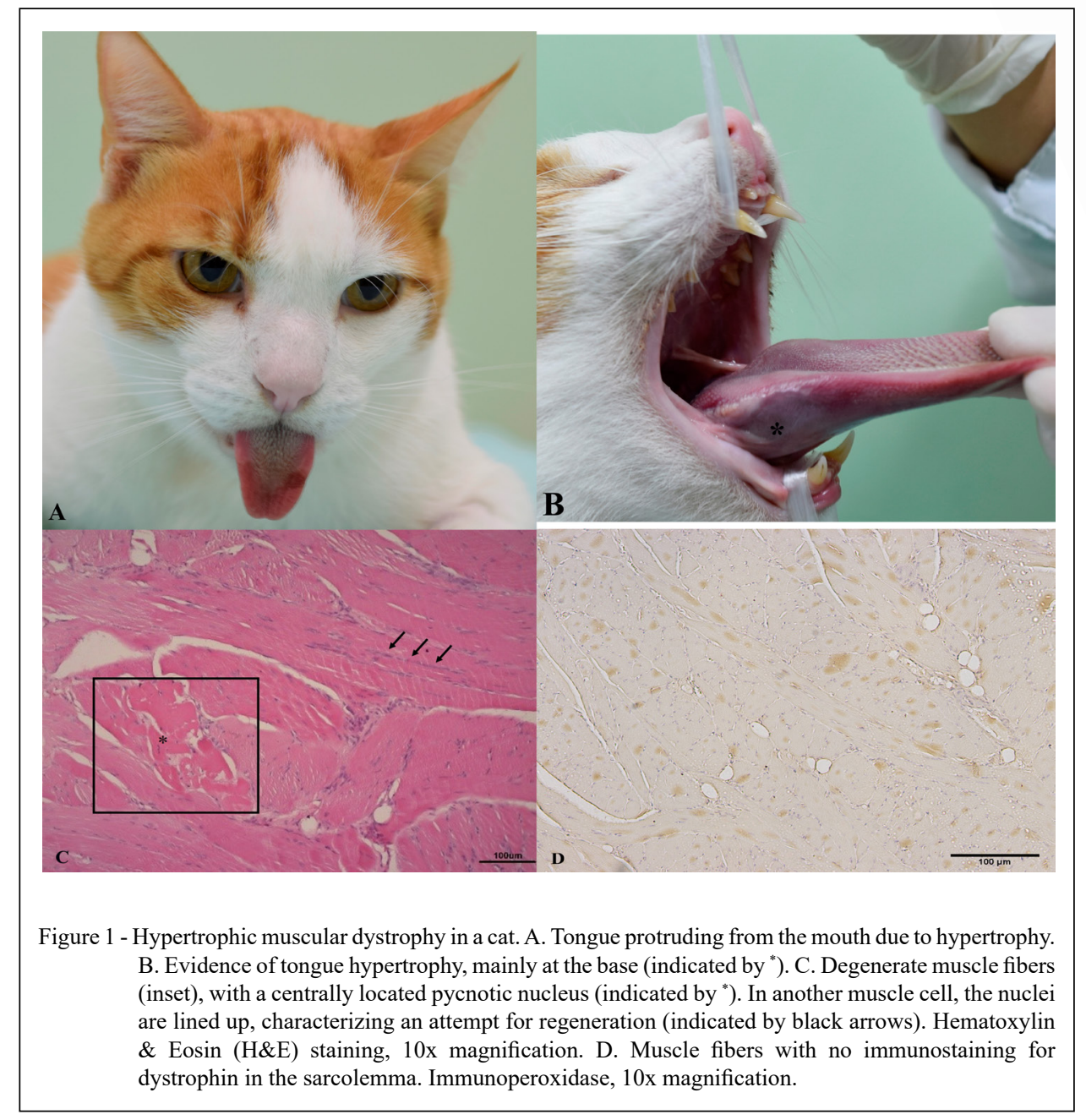

commencement of signs for anorexia and prostration approximately 10 days before the appointment.

On physical examination, a bilateral symmetrical increase in volume at the base of the tongue (Figure 1B), hypertrophy of the axial and appendicular muscles, and lesions in the oral mucosa were observed. On neurological examination, the cat presented ambulatory tetraparesis without signs of proprioceptive ataxia during movement. Given this situation, it was admitted for oral cavity inspection and complementary examinations, including blood count, serum biochemistry, chest radiography, abdominal ultrasonography, and echocardiography.

On radiographic examination of the pharynx and larynx, an increase in the volume of the tongue over its entire length was evident, resulting in narrowing of the oropharynx. The chest showed an increase in the volume of the cardiac margin, with a vertebral heart score 8.3 (reference, $7.3 \pm 0.5$ ), compatible with a global ventricular enlargement (LITSTER; BUCHANAN, 2000). Echocardiography revealed mild concentric hypertrophy of the left ventricle with free wall of the left ventricle on diastole being $0.61 \mathrm{~cm}$ (reference, $0.48 \pm 0.07 \mathrm{~cm}$ ), and interventricular septum on diastole being $0.59 \mathrm{~cm}$ (reference, $0.49 \pm 0.07 \mathrm{~cm}$ ), with no signs of heart failure (BROWN et al., 2003).

On abdominal ultrasound, lengths of the kidneys (right, $4.7 \mathrm{~cm}$ and left,4.65 cm; reference, 3.0 to $4.5 \mathrm{~cm}$ ) were found to increase and the liver showed smooth contours, margins with rounded angles. Further, adrenals (right, $1.66 \times 0.7 \mathrm{~cm}$; left, $1.44 \times 0.8 \mathrm{~cm}$; reference, 1.0 to $1.1 \mathrm{~cm}$ in length; $0.43 \pm 0.03 \mathrm{~cm}$ in diameter) and the spleen increased 
in size, and the muscular layer of the stomach wall $(0.38 \mathrm{~cm}$; reference, 0.16 to $0.36 \mathrm{~cm})$ and intestinal tract $(0.33 \mathrm{~cm}$; reference, 0.2 to $0.25 \mathrm{~cm})$ were reported to be thickened (PENNINCK; D 'ANJOU, 2015). Results of the serum biochemistry analysis showed high values of alanine aminotransferase (ALT)(129.0 IU/1; reference, 6 to $83 \mathrm{IU} / 1)$, aspartate aminotransferase (AST)(128.0 IU/1; reference, 23 to $43 \mathrm{IU} / 1)$, and creatine kinase $(\mathrm{CK})(2893.0 \mathrm{IU} / \mathrm{l}$; reference, 7.2 to $28.2 \mathrm{IU} / 1$ ).

An incisional biopsy at the base of the tongue was performed under general anesthesia to collect the muscle fragments. Three samples were also collected from the upper right and left lateral sides of the base of the tongue with the aid of a semiautomatic TRU-CUT needle.

Histopathological tests revealed the presence of diffusely thickened muscle fibers (hypertrophy), with degeneration and necrosis, interspersed with fibrous tissue, and areas of muscle regeneration (Figure $1 \mathrm{C}$ ).

The clinical-histopathological diagnosis of HFMD was confirmed through immunohistochemistry using the primary anti-dystrophin antibody (Dystrophin Polyclonal Antibody, 1:200; bs-6718R BIOSS). Immunostaining of the tongue samples showed the absence of dystrophin in the sarcolemma (Figure 1D), confirming the diagnosis of dystrophin deficiency.

No treatment was instituted for this animal due to the absence of any specific therapy for the disease (GASCHEN et al., 2004). However, food management was changed to avoid signs of anorexia and dysphagia. The animal's diet was modified comprising smaller grain, in addition to wet food (commercial supply), in limited quantities, several times a day. With the intent of improving water intake, additional water fountains were added throughout the house, apart from adding water to the dry food.

HFMD is a rare, sporadically reported disorder that mainly affects young male cats (CARPENTER et al., 1989; GASCHEN et al., 1992, 1999; CHETBOUL et al., 2006; VAN SOENS et al., 2009; BLUNDEN \& GOWER, 2011). However, compared with previous reports, our case described the first clinical signs detected in a three-year-old cat. The clinical features of cats with HFMD include hypertrophy of the appendicular and axial skeletal muscles, organomegaly, changes in gait characterized by weakness, and an increased volume and protrusion of the tongue (VAN SOENS et al., 2009; BLUNDEN \& GOWER, 2011), which is in line with most of the clinical findings in this report.
Organomegaly in cats with HFMD is caused by hypertrophy of muscle fibers (CARPENTER et al., 1989; GASCHEN et al., 1992, 1999; CHETBOUL et al., 2006). Differential diagnoses for organomegaly are acute kidney disease, diffuse hyperplastic, infiltrative, or infectious/inflammatory lesions, or neoplasms (PENNINCK; D'ANJOU, 2015). However, in this case, no clinical signs were detected that could be evidence for these diseases, indicating that organomegaly was associated with HFMD.

The diagnosis of HFMD was based on the clinical presentation, complimentary examination findings (imaging and laboratory), and histopathological and immunohistochemical reports. The increase in serum ALT, AST, and CK was indicative of muscle disease. The elevation of these soluble cytoplasmic enzymes of myofibrils occurs due to the necrosis of muscle fibers or leakage of the cytoplasm due to the generalized instability of the plasma membrane myofibrils (SHELTON \& ENGVALL, 2002; GASCHEN et al. 2004).

HFMD can affect the myocardium to different degrees and cause mild to moderate cardiomegaly, as seen using radiographic and echocardiographic examinations. However, these changes rarely produce clinically detectable signals (CHETBOUL et al., 2006). In this study, the cat had concentric hypertrophy in the left ventricle, with no clinical signs of cardiomyopathy. This change might be related to HFMD; nevertheless, we could not disregard feline idiopathic hypertrophic cardiomyopathy, which is also characterized by left ventricular hypertrophy. Secondary causes of cardiomyopathy, such as hyperthyroidism or subaortic stenosis, were not observed in this case (ABBOTT, 2010).

Due to the progressive nature of the disease, chest radiography and echocardiography can provide important information for monitoring the disease progression (GASCHEN et al., 1999). The histopathological findings in this report, characterized by hypertrophy of muscle fibers, foci of necrotic fibers interspersed with fibrous tissue, and regeneration fibers (Figure 1D), were consistent with other reported cases of HFMD (GASCHEN et al., 1992, 1999; CHETBOUL et al., 2006).

After 22 months of diagnosis, the cat did not show any worsening of clinical, laboratory, and imaging features (radiography, ultrasound, and echocardiography). This phenomenon differed from previous studies which reported clinical complications leading to death or euthanasia of the animals (SHELTON; ENGVALL, 2002). The 
variations in clinical manifestations and evolution in cats with HFMD are unclear and poorly described. Nevertheless, in humans and dogs with muscular dystrophy with dystrophin deficiency, this variation has been described and attributed to the intensity of deletions that occur in the DNA, the mutation site of the dystrophin gene, the phenotypic differences, and the amount of dystrophin produced (GUTMANN; FISCHBECK, 1989; AMBROSIO et al., 2009; DE LAHUNTA, 2009). In the study by Ambrosio et al. (2009), dogs from the same litter had different phenotypes, resulting in the pathology evolving at different rates.

The cat's survival in this report was possibly related to the fact that it did not present any visible changes for diaphragmatic hypertrophy, megaesophagus, heart failure, and rhabdomyolysis, which are considered to contribute to the poor prognosis of the disease (VAN SOENS et al., 2009; BLUNDEN \& GOWER, 2011). Further, this case indicated the importance of care through food management and water intake, considering that the main clinical complications described were related to dysphagia and anorexia secondary to tongue hypertrophy. Such complications can lead to decreased water intake and hyperosmolar syndrome with acute renal failure (GASCHEN et al., 1999).

In conclusion, hypertrophic feline muscular dystrophy should be considered even in adult cats presenting the typical clinical features of the disease. The diagnosis must be based on the histopathological and immunohistochemical findings including hypertrophy of the muscles, protrusion of the tongue, increase in serum ALT, AST, and CK, and increased cardiac, hepatic, and renal silhouette. It is a disease that can cause serious complications and lead the owners to opt for euthanasia; however, supportive measures and adequate food management can increase survival and improve the quality of life of cats with the disease.

\section{DECLARATION OF CONFLICT OF INTEREST}

There are no conflicts of interest to declare.

\section{ACKNOWLEDGMENTS}

This study was financially supported by the Conselho Nacional de Desenvolvimento Científico e Tecnológico $(\mathrm{CNPq}$ / process number: 307120-2017-1) and was financed in part by the Coordenação de Aperfeiçoamento de Pessoal de Nível Superior (CAPES), Brasil - Finance code 001. We acknowledge the Faculdade de Medicina Veterinária e Zootecnia (FMVZ) of the Universidade de São Paulo (USP) for performing the immunohistochemical study.

\section{AUTHORS' CONTRIBUTION}

The authors contributed equally to the manuscript.

\section{REFERENCES}

ABBOTT, J. A. Feline hypertrophic cardiomyopathy: an update. Veterinary Clinics Of North America: Small Animal Practice, [S.L.], v.40, n.4, p.685-700, jul. 2010. Elsevier BV. Available from: $<$ http://dx.doi.org/10.1016/j.cvsm.2010.04.004.>. Accessed: Feb. 01, 2021. doi: 10.1016/j.cvsm.2010.04.004.

AMBROSIO, C. et al. Identification of three distinguishable phenotypes in golden retriever muscular dystrophy. Genetics And Molecular Research, [S.L.], v.8, n.2, p.389-396, 2009. Available from: <http://dx.doi.org/10.4238/vol8-2gmr581.>.Accessed: Feb. 01, 2021. doi: 10.4238/vol8-2gmr581.

BLUNDEN, A.S.; GOWER, S.P. Hypertrophic feline muscular dystrophy: diagnostic overview and a novel immunohistochemical diagnostic method using formalin-fixed tissue. Veterinary Record, v.168, n.19, p.510, 2011. Available from: $<$ https://doi.org/10.1136/ vr.d1119>. Accessed: Feb. 01, 2021. doi: 10.1136/vr.d1119.

BROWN, D. J. et al. M-Mode echocardiographic ratio indices in normal dogs, cats, and horses: a novel quantitative method. Journal Of Veterinary Internal Medicine, [S.L.], v.17, n.5, p.653-662, set. 2003. Wiley.Available from: <http://dx.doi. org/10.1111/j.1939-1676.2003.tb02496.x.>. Accessed: Feb. 01, 2021. doi: 10.1111/j.1939-1676.2003.tb02496.x.

CARPENTER, J. L. et al. Feline muscular dystrophy with dystrophin deficiency. American Journal Pathology, v.135, n.5, p.909-919, 1989. Available from: <http://www.ncbi.nlm.nih.gov/ entrez/query.fcgi? $\mathrm{cmd}=$ Retrieve $\& \mathrm{db}=$ PubMed $\&$ dopt $=$ Citation $\&$ li st_uids $=2683799>$. Accessed: Feb. 01, 2021.

CHETBOUL, V. et al. Tissue doppler imaging for detection of radial and longitudinal myocardial dysfunction in a family of cats affected by dystrophin-deficient hypertrophic muscular dystrophy. Journal of Veterinary Internal Medicine, v.20, n.3, p.640-647, 2006. Available from: <https://www.ncbi.nlm. nih.gov/pubmed/16734102>. Accessed: Feb. 01, 2021. doi: 10.1892/0891-6640(2006)20[640:tdifdo]2.0.co;2.

DE LAHUNTA, A. Veterinary neuroanatomy and clinical neurology. 3rd ed. St. Louis: Saunders, 2009, 540 p.

GASCHEN, F; et al. Congenital diseases of feline muscle and neuromuscular junction. Journal of Feline Medicine and Surgery, v.6, n.6, p.355-366, 2004. Available from: <https://www. ncbi.nlm.nih.gov/pubmed/15546767>. Accessed: Feb. 01, 2021. doi: $10.1016 /$ j.jfms.2004.02.003.

GASCHEN, F.P. et al. Dystrophin deficiency causes lethal muscle hypertrophy in cats. Journal Neurological Sciences, v.110, n.1-2, p.149-159, 1992. Available from: <https://www.ncbi. nlm.nih.gov/pubmed/1506854>. Accessed: Feb. 01, 2021. doi: 10.1016/0022-510x(92)90022-d.

GASCHEN, L. et al. Cardiomyopathy in dystrophindeficient hypertrophic feline muscular dystrophy. Journal 
of Veterinary Internal Medicine, v.13, n.4, p.346-356, 1999. Available from: <https://onlinelibrary.wiley.com/doi/ pdf/10.1111/j.1939-1676.1999.tb02193.x>. Accessed: Feb. 01, 2021. doi: 10.1111/j.1939-1676.1999.tb02193.x.

GUTMANN, D. H.; FISCHBECK, K. H. Molecular biology of duchenne and Becker's muscular dystrophy: clinical applications. Annals Of Neurology, [S.L.], v.26, n.2, p.189-194, ago. 1989. Wiley.Available from: <http://dx.doi.org/10.1002/ana.410260202.>. Accessed: Feb. 01, 2021. doi: 10.1002/ana.410260202.

KORNEGAY, J.N. et al. Muscular dystrophy in a litter of golden retriever dogs. Muscle \& Nerve, v.11, n.10, p.1056-1064, 1988. Available from: $<$ https://onlinelibrary.wiley.com/doi/abs/10.1002/mus.880111008>. Accessed: Feb. 01, 2021. doi: 10.1002/mus.880111008.

LITSTER, A. L.; BUCHANAN, J. W. Vertebral scale system to measure heart size in radiographs of cats. Journal Of The American Veterinary Medical Association, [S.L.], v.216, n.2, p.210-214, jan. 2000. American Veterinary Medical Association (AVMA). Available from: <http://dx.doi.org/10.2460/javma.2000.216.210>. Accessed: Feb. 01, 2021. doi: 10.2460/javma.2000.216.210.

PENNINCK, D.; D'ANJOU, M. Atlas of Small Animal Ultrasonography. 2. ed. Iowa: Wiley, 2015. 570 p.
SHELTON, G.D.; ENGVALL, E. Muscular dystrophies and other inherited myopathies. Veterinary Clinics of North America. Small Animal Practice, v.32, n.1, p.103-124, 2002. Available from: $\quad<$ https://www.ncbi.nlm.nih.gov/pubmed/11785725> Accessed: Feb. 01, 2021. doi: 10.1016/s0195-5616(03)00081-0.

TORRES, L.F.B.; DUCHEN, L.W. The mutant mdx: inherited myopathy in the mouse. Morphological studies of nerves, muscles and end-plates. Brain, v.110, n.2, p.269-299, 2007. Available from: $\quad<$ https://www.ncbi.nlm.nih.gov/pubmed/3567525>. Accessed: Feb. 01, 2021. doi: 10.1093/brain/110.2.269.

VAN SOENS, I. et al. A case of hypertrophyc feline muscular dystrophy in a belgian domestic shorthair cat. Vlaams Diergeneeskundig Tijdschrift, v.78, p.111-115, 2009. Available from: $<$ http://vdt.ugent.be/sites/default/files/ art78207.pdf>. Accessed: Feb. 01, 2021.

YUASA, K. et al. Dystrophin deficiency in canine X-linked muscular dystrophy in Japan (CXMDJ) alters myosin heavy chain expression profiles in the diaphragm more markedly than in the tibialis cranialis muscle. BMC Musculoskeletal Disorders, v.9, p.1-12, 2008. Available from: <https://www.ncbi.nlm. nih.gov/pubmed/18182116>. Accessed: Feb. 01, 2021. doi: 10.1186/1471-2474-9-1. 